\title{
Cell based therapy for the management of chronic pain
}

\author{
Younghoon Jeon \\ Department of Anesthesiology and Pain Medicine, School of Dentistry, Kyungpook National University, Daegu, Korea
}

The management of chronic pain, particularly neuropathic pain, still has significant unmet needs. In addition to inadequate symptomatic relief, there are concerns about adverse effects and addiction associated with treatments. The transplantation of cells that secrete neuroactive substances with analgesic properties into the central nervous system has only become of practical interest in more recent years, but provides a novel strategy to challenge current approaches in treating chronic pain. This review covers pre-clinical and clinical studies from both allogeneic and xenogeneic sources for management of chronic refractory pain. (Korean J Anesthesiol 2011; 60: 3-7)

Key Words: Cell therapy, Chronic pain, Encapsulated cells, Gene therapy, Genetically modified cells.

\section{Introduction}

Chronic pain of different etiologies affects brain structure and function [1]. It may cause other symptoms or conditions, including depression and anxiety, and may also contribute to decreased physical activity given the apprehension of exacerbating pain [2]. Despite recent advances in our understanding of chronic pain mechanisms and normal nociceptive transmission, the management of chronic pain, particularly neuropathic pain, is still far from resolved with currently available therapeutic regimens. Although many effective treatments are available, a number of adverse effects that interfere with the quality of life may be associated with treatment, and a significant number of patients obtain no relief from these treatments. Therefore, chronic pain is a major medical and societal problems resulting in enormous financial costs [3].

Transplanting cells that secrete neuroactive substances with analgesic properties into the central nervous system (CNS) may have therapeutic potential for the long-term treatment of chronic pain [4-7]. Cell transplantation could provide analgesic effects similar to neuraxial drug delivery pumps such as the secretion of pain-reducing neuroactive substances at optimal sites and constant level, while overcoming problems of pump refilling and maintenance. In addition, these cellbased approaches targeted to the CNS could alleviate most systemic side effects. Therefore, the selection of appropriate bioengineered cells as biological mini pumps can provide permanent management of chronic pain. This review focuses on the role of cell-based therapy in the management of chronic pain.

\section{The Mechanism of Cell Based Therapy for Pain}

Cell transplants for pain are based on the concept of descending inhibitory modulation of sensory information. Descending inhibitory tracts from cell bodies in the periaqueductal

Received: June 21, 2010. Revised: July 14, 2010. Accepted: July 14, 2010.

Corresponding author: Younghoon Jeon, M.D., Ph.D., Department of Anesthesiology and Pain Medicine, School of Dentistry, Kyungpook National University, 188-1, Samdeok-dong 2 Ga, Jung-gu, Daegu 700-421, Korea. Tel: 82-53-420-5871, Fax: 82-53-426-2760, E-mail: jeon68@knu.ac.kr (c) This is an open-access article distributed under the terms of the Creative Commons Attribution Non-Commercial License (http:// creativecommons.org/licenses/by-nc/3.0/), which permits unrestricted non-commercial use, distribution, and reproduction in any medium, provided the original work is properly cited. 
gray, reticular formation, and nucleus magnus project to the dorsal horn. These inhibitory tracts contain a variety of neurotransmitters, including catecholamines and opioids, which play an important role in nociceptive responses $[8,9]$. Chromaffin cells [4-7], neural precursor cells [10], mesenchymal stem cells [11], and genetically engineered cells [12] can secrete neuroactive materials, including catecholamines, opioid peptides, and other neuropeptides with anti-nociceptive properties. Intrathecal transplantation of these cells induces analgesia in animal pain models.

\section{Biomaterial Technology for Cell Implantation}

One of the biggest issues for organ transplantation is the shortage of donor tissues or organs. The low number of available grafts requires the use of xenogenic non-human donors, but the transplants undergo immunological rejection, limiting their survival. In addition, the continuous use of immunosuppressive agents to prevent immunological rejection often causes side effects, such as bacterial or viral infection and carcinogenesis. Analgesic effects correlate with graft viability and output $[6,7,13]$, and xenogenic grafts are frequently rejected. Therefore, protecting grafts from immunological responses by encapsulating them within a semipermeable membrane using biocompatible materials allows for immunoisolation, which permits the inward diffusion of small molecule nutrients and oxygen, and outward diffusion of therapeutic material produced by implants, but preventing host immune system responses and improving long-term graft survival without immunosuppressants [5-7].

One common design for microencapsulation involves enclosing cells within the lumen of a semipermeable membrane or flat sheet membrane of polyacrylonitrile/polyvinylchloride fiber [13]. For macroencapsulation, cells are usually suspended in a matrix within a hollow fiber membrane. The open ends of the hollow fiber are sealed, thereby forming a capsule within which the cells reside. The advantages of this technique include stability of the implant and ease of retrieval. However, the relatively thick fiber membrane is disadvantageous for cell viability and the efficient release of neuroactive materials, because there is a relatively large diffusion distance across the membrane. The loss of cell viability, in particular, severely limits the usefulness of macrocapsules [13]. This low grafting rate of cells transplanted and their consequent poor functions often cause low therapeutic efficacy of cell transplantation. Cells must have a suitable environment to overcome these problems. Microcapsules are much smaller, durable, and typically have a larger surface to volume ratio that is advantageous for the bi-directional diffusion of nutrients, oxygen, and bioactive materials, compared to macrocapsules. Therefore, microcapsules are more effective for the delivery of analgesic substances by transmembrane diffusion than macrocapsules [5-7]. In addition, the dimensions of microcapsules can be scaled easily to suit different species and implantation sites, although they are fragile and cannot be retrieved easily.

\section{Application of Cell-based Therapies for Pain}

\section{Chromaffin cells}

Chromaffin cells produce and release catecholamines, opioid peptides of various sizes, and other neuropeptides that produce analgesia in the spinal space [5-7,14]. Cerebrospinal fluid (CSF) in a neuropathic pain model induced by loose ligation of the sciatic nerve induces catecholamines release from chromaffin cells [15]. Long-term survival of intrathecally implanted encapsulated bovine chromaffin cells reduced mechanical and cold allodynia in a rat model of neuropathic pain [5-7]. In addition, norepinephrine and met-enkephalin levels of CSF were higher in the rats that received microencapsulated chromaffin cells [6]. However, due to concerns over the risk of prion transmission, the use of bovine adrenal medulla may be precluded in future clinical trials. Intrathecal porcine chromaffin cells also suppress nociceptive behavior in animal pain models $[16,17]$.

\section{Neural precursor cells}

Chromaffin cells stem from the neural crest, which plays a paradigmatic role in the mechanism that determines cell fate in the nervous system. Two types of fetal human chromaffin cells with an adrenergic phenotype between 7 and 10 gestational weeks could be obtained in vitro [18] through specific procedures, but these cells could be exploited for pain therapy [19]. Allodynia after injury may involve the pathological loss of inhibition in the spinal cord [20]. Following spinal cord or peripheral nerve injury, there is an apparent loss of $\gamma$-aminobutyric acid (GABA) ergic inhibitory interneurons in the spinal cord [21]. Bioreactor-expanded human neural precursor cells differentiated to a GABAergic phenotype prior to transplantation decreased allodynia in rat model of neuropathic pain induced by ligation of the spinal nerve [10].

\section{Stem cells}

Stem cells hold great potential for the regeneration of damaged tissues [22]. They limit neuronal damage in a wide variety of experimental neurologic injuries, including Parkinson's disease [23], spinal cord injury [24], and peripheral nerve damage [25]. Intra-brain microinjection of human 
mesenchymal stem cells (hMSC) reduced the mRNA levels of the proinflammatory interleukin-1beta gene, as well as astrocytic and microglial cell activation in neuropathic mice [26]. In vitro, genetically engineered hMSCs transfected with the human preproenkephalin (hPPE) gene increased production of the opioid peptide, met-enkephalin [11]. In addition, hybrid cell fusions of chromaffin cells and hMSCs expressed some characteristics of the chromaffin cell phenotype, suggesting that novel cellular production could be developed by a "reprogramming" mechanism through the application of targeted cell fusion strategies [27]. Stem cells can provide a sufficient number of chromaffin cells due to the paucity of human adrenal tissue.

\section{Cell lines}

Immortalized cell lines are an alternative to chromaffin cells for cellular implantation, offering the advantage of shelf availability as well as a more detailed characterization of their phenotype and histocompatibility. The most useful cell lines are derived from chromaffin cells, with ongoing creation of human chromaffin cell lines that may be useful in treating traumatic and neurodegenerative disease [28-31]. Initially, the archetypal adrenal medullary cell lines were derived from spontaneous pheochromocytoma of the medulla, either from murine or human sources, such as the rat PC12 cell line and the human KNA and KAT45 cell lines [28-30]. Modern techniques use tumorigenesis and targeted oncogenesis in vivo, where isolation of specific populations of mouse endocrine cells allows exploration of the regulatory pathways in the chromaffin phenotype [31]. In addition, conditional immortalization with retroviral infection of chromaffin precursors has provided homogeneous and expandable chromaffin cells for transplant studies in animal models of pain [32]. This same strategy of immortalization with conditionally expressed oncogenes has been expanded to create the first disimmortalizable chromaffin cells, with an excisable oncogenic cassette, as might be envisioned for the creation of human chromaffin cell lines $[33,34]$.

The use of monoamine-secreting cell lines for the continuous delivery of catecholamines and/or serotonin to the spinal cord may be an alternative strategy for the treatment of chronic pain. An encapsulated neuroblastoma cell line NB69 given intrathecally produced analgesia to neuropathic pain in rats by producing monoamines (dopamine and serotonin) [35]. Immortalized chromaffin cells of rats were genetically modified to improve opioid peptide expression through lipid-mediated gene transfer. When implanted into the spinal space, they reduced evoked c-fos protein expression in rat dorsal horn neurons in the formalin tonic pain model [36]. The use of such expandable cell lines for chronic spinal delivery of opiates could offer an attractive and safe alternative strategy based on ex vivo gene therapy for the control of opioid-sensitive chronic pain.

\section{Macrophages}

An ex vivo gene transfer of the human proenkephalin gene to autologous macrophages of rats was performed with a non-viral vector. Intrathecal implantation of these cells alleviated heat hyperalgesia and allodynia induced by sciatic nerve constriction for four weeks. The transplanted macrophages migrated into the spinal cord and expressed proenkephalin mRNA and metenkephalin protein [37].

\section{Clinical trial}

Clinical trials with allografts consisting of whole-tissue fragments implanted into the subarachnoid space of the lumbar spinal cord showed that the allogeneic grafts could control cancer pain in two patients over 1 year based on patient reported pain scores, morphine intake, and CSF levels of met-enkephalin [38]. A Phase II open study in France showed the feasibility and the safety of chromaffin cell allografts administered intrathecally to cancer patients to relieve intractable pain [39]. The CNS is considered an immune privileged site. Non-human leukocyte antigen (HLA)matched and unencapsulated tissue was grafted and analgesic efficacy was indicated by the reduction or stabilization in complementary opioid intake, although lymphocyte counts increased in CSF. Further work on the purification and/or the immunoisolation of tissues grafted in the CNS will be necessary, particularly for long-term or repeated grafting.

\section{Conclusions}

Cell based treatment offers certain benefits in controlled, safe, long-term delivery of analgesic molecules in experimental cell-based therapies. In addition, novel technologies such as encapsulation and engineered cell lines hold promise for future applications. Initial clinical trials have been generally encouraging, although evidence for translation into clinical use in humans is limited. Together, these studies suggest that cell transplantation is a potentially valuable complementary approach in the therapeutic management of chronic pain.

\section{References}

1. Baliki MN, Geha PY, Apkarian AV, Chialvo DR. Beyond feeling: chronic pain hurts the brain, disrupting the default-mode network dynamics. J Neurosci 2008; 28: 1398-403. 
2. Pruimboom L, van Dam AC. Chronic pain: a non-use disease. Med Hypotheses 2007; 68: 506-11.

3. Gureje O, Von Korff M, Simon GE, Gater R. Persistent pain and well-being: a World Health Organization Study in Primary Care. JAMA1998; 280: 147-51.

4. Siegan JB, Sagen J. Attenuation of formalin pain responses in the rat by adrenal medullary transplants in the spinal subarachnoid space. Pain 1997; 70: 279-85.

5. Baek WY, Kim HG, Kim YM, Lim JO, Jeon YH. Microencapsulated bovine adrenal medullary chromaffin cells transplanted into rat spinal cord alleviated cold allodynia. Korean J Anesthesiol 2004; 46: 354-9.

6. Jeon Y, Kwak K, Kim S, Kim Y, Lim J, Baek W. Intrathecal implants of microencapsulated xenogenic chromaffin cells provide a long-term source of analgesic substances. Transplant Proc 2006; 38: 3061-5.

7. Kim YM, Jeon YH, Jin GC, Lim JO, Baek WY. Immunoisolated chromaffin cells implanted into the subarachnoid space of rats reduce cold allodynia in a model of neuropathic pain: a novel application of microencapsulation technology. Artif Organs 2004; 28: 1059-66.

8. Zieglgänsberger W, Tulloch IF. The effects of methionine- and leucine-enkephalin on spinal neurons of the cat. Brain Res 1979; 167: 53-64.

9. Reddy SV, Maderdrut JL, Yaksh TL. Spinal cord pharmacology of adrenergic agonist-mediated antinociception. J Pharmacol Exp Ther 1980; 213: 525-33.

10. Mukhida K, Mendez I, McLeod M, Kobayashi N, Haughn C, Milne B, et al. Spinal GABAergic transplants attenuate mechanical allodynia in a rat model of neuropathic pain. Stem Cells 2007; 25: 2874-85.

11. Sugaya I, Qu T, Sugaya K, Pappas GD. Genetically engineered human mesenchymal stem cells produce met-enkephalin at augmented higher levels in vitro. Cell Transplant 2006; 15: 225-30.

12. Eaton MJ, Plunkett JA, Martinez MA, Lopez T, Karmally S, Cejas P, et al. Transplants of neuronal cells bioengineered to synthesize GABA alleviate chronic neuropathic pain. Cell Transplant 1999; 8: 87-101.

13. Décosterd I, Buchser E, Gilliard N, Saydoff J, Zurn AD, Aebischer P. Intrathecal implants of bovine chromaffin cells alleviate mechanical allodynia in a rat model of neuropathic pain. Pain 1998; 76: 159-66.

14. Park JM, Kim SJ, Kwak KH, Jeon YH, Baek WY. Quantitative analysis of secreted catecholamines from chromaffin cells in vitro and in vivo. Korean J Anesthesiol 2005; 49: 235-40.

15. Hentall ID, Sagen J. Spinal CSF from rats with painful peripheral neuropathy evokes catecholamine release from chromaffin cells in vitro. Neurosci Lett 2000; 286: 95-8.

16. Lu Y, Jing R, Yeomans DC, Pappas GD. Porcine chromaffin cells, culture, and transplant for antinociceptive effects in rodents and primates. Neurol Res 2004; 26: 707-12.

17. Sol JC, Li RY, Sallerin B, Jozan S, Zhou H, Lauwers-Cances V, et al. Intrathecal grafting of porcine chromaffin cells reduces formalinevoked c-Fos expression in the rat spinal cord. Cell Transplant 2005; 14: 353-65.

18. Zhou H, Aziza J, Sol JC, Courtade-Saïdi M, Chatelin S, Evra C, et al. Cell therapy of pain: characterization of human fetal chromaffin cells at early adrenal medulla development. Exp Neurol 2006; 198: 370-81.

19. Jozan S, Aziza J, Châtelin S, Evra C, Courtade-Saïdi M, Parant O, et al. Human fetal chromaffin cells: a potential tool for cell pain therapy. Exp Neurol 2007; 205: 525-35.

20. Mayer DJ, Price DD, Becker DP. Neurophysiological characterization of the anterolateral spinal cord neurons contributing to pain perception in man. Pain 1975; 1: 51-8.

21. Woolf CJ; American College of Physicians; American Physiological Society. Pain: moving from symptom control toward mechanismspecific pharmacologic management. Ann Intern Med 2004; 140: 441-51.

22. Short B, Brouard N, Occhiodoro-Scott T, Ramakrishnan A, Simmons PJ. Mesenchymal stem cells. Arch Med Res 2003; 34: 565-71.

23. Lindvall O, Kokaia Z. Stem cells for the treatment of neurological disorders. Nature 2006; 441: 1094-6.

24. Cao Q, Benton RL, Whittemore SR. Stem cell repair of central nervous system injury. J Neurosci Res 2002; 68: 501-10.

25. Siniscalco D, Rossi F, Maione S. Molecular approaches for neuropathic pain treatment. Curr Med Chem 2007; 14: 1783-7.

26. Siniscalco D, Giordano C, Galderisi U, Luongo L, Alessio N, Di Bernardo G, et al. Intra-brain microinjection of human mesenchymal stem cells decreases allodynia in neuropathic mice. Cell Mol Life Sci 2010; 67: 655-69.

27. Shi G, Ma K, Pappas GD, Qu T. Phenotypic characteristics of hybrid cells produced by cell fusion of porcine adrenal chromaffin cells with human mesenchymal stem cells: a preliminary study. Neurol Res 2008; 30: 217-22.

28. Pfragner R, Behmel A, Smith DP, Ponder BA, Wirnsberger G, Rinner I, et al. First continuous human pheochromocytoma cell line: KNA. Biological, cytogenetic and molecular characterization of KNA cells. J Neurocytol 1998; 27: 175-86.

29. Greene LA, Tischler AS. Establishment of a noradrenergic clonal line of rat adrenal pheochromocytoma cells which respond to nerve growth factor. Proc Natl Acad Sci USA 1976; 73: 2424-8.

30. Venihaki M, Gravanis A, Margioris AN. KAT45 human pheochromacytoma cell line. A new model for the in vitro study of neuro-immuno-hormonal interactions. Ann N Y Acad Sci 1998; 840: 425-33.

31. Powers JF, Evinger MJ, Tsokas P, Bedri S, Alroy J, Shahsavari M, et al. Pheochromocytoma cell lines from heterozygous neurofibromatosis knockout mice. Cell Tissue Res 2000; 302: 309-20.

32. Obinata M. Conditionally immortalized cell lines with differentiated functions established from temperature-sensitive T-antigen transgenic mice. Genes Cells 1997; 2: 235-44.

33. Eaton MJ. Emerging cell and molecular strategies for the study and treatment of painful peripheral neuropathies. J Peripher Nerv Syst 2000; 5: 59-74.

34. Eaton MJ, Herman JP, Jullien N, Lopez TL, Martinez M, Huang J. Immortalized chromaffin cells disimmortalized with Cre/lox sitedirected recombination for use in cell therapy for pain after partial nerve injury. Exp Neurol 2002; 175: 49-60.

35. De la Calle JL, Mena MA, González-Escalada JR, Paíno CL. Intrathecal transplantation of neuroblastoma cells decreases heat hyperalgesia and cold allodynia in a rat model of neuropathic pain. Brain Res Bull 2002; 59: 205-11.

36. Duplan H, Li RY, Vue C, Zhou H, Emorine L, Herman JP, et al. Grafts of immortalized chromaffin cells bio-engineered to improve metenkephalin release also reduce formalin-evoked c-fos expression in rat spinal cord. Neurosci Lett 2004; 370: 1-6.

37. Hino M, Ogata T, Morino T, Horiuchi H, Yamamoto H. Intrathecal 
transplantation of autologous macrophages genetically modified to secrete proenkephalin ameliorated hyperalgesia and allodynia following peripheral nerve injury in rats. Neurosci Res 2009; 64: 5662.

38. Bés JC, Tkaczuk J, Czech KA, Tafani M, Bastide R, Caratero C, et al. One-year chromaffin cell allograft survival in cancer patients with chronic pain: morphological and functional evidence. Cell Transplant 1998; 7: 227-38.

39. Lazorthes Y, Sagen J, Sallerin B, Tkaczuk J, Duplan H, Sol JC, et al. Human chromaffin cell graft into the CSF for cancer pain management: a prospective phase II clinical study. Pain 2000; 87: 19-32. 